\title{
Estimation of the Effect of Drought on Yield and Yield Contributing Traits in Coriander Genotypes (Coriandrum sativum L.)
}

\author{
Mamta Bajya*, B.L. Kakralya, Kamlesh Jangid and Anita Burdak \\ Department of Plant Physiology, SKN College of Agriculture, Jobner, Jaipur, Rajasthan, India \\ *Corresponding author
}

\author{
A B S T R A C T
}

Keywords

Drought, Yield traits, Coriander, Varieties and test weight.

Article Info

Accepted:

14 June 2017

Available Online:

10 August 2017
Eight Coriander varieties viz. Rcr-20, Rcr-41, Rcr-435, Rcr-436, Rcr-446, Rcr475, Rcr-684 and Rcr-728 were conducted at the research farm of S.K.N. College of Agriculture, Jobner, Jaipur (Rajasthan) during Rabi, 2016 in randomized block design with three replications on loamy sand soil. Under control condition plot were irrigated at regular interval while in drought condition plots were maintained under rainfed condition. Yield and yield contributing parameters were recorded at maturity stages and after harvesting. The Coriander varieties Rcr-20 and Rcr-446 behaved as drought tolerance varieties maintained higher seed yield along with number of umbels per plant, seeds per umbel, test weight, seed yield, biological yield, harvest index under drought conditions. The coriander varieties Rcr-435 and Rcr-728 maintained under higher seed yield along with number of umbels per plant, seeds per umbel, test weight, seed yield, biological yield, harvest index under control conditions.

\section{Introduction}

Coriander (Coriandrum sativum L.) is an important seed spice crop a member of family Apiaceae, a tall herbaceous annual diploid $(2 n=22)$. It is highly cross pollinated crop believed to be native of Mediterranean region. The dry seed contains 6.3 per cent moisture, 1.3 per cent protein, $0.3-0.4$ per cent volatile oil, 19.6 per cent nonvolatile oil, 24.6 per cent carbohydrates and 5.3 percent mineral matter. In Rajasthan it is mainly grown in the district of Baran, Kota, Bundi, Chittorgarh and Jhalawar with an area of 212725 ha and annual production of 227203 tones (Anonymous, 2015-2016). Drought is a meteorological term and is commonly defined as a period without significant rainfall. It is one of the most universal and significant environmental stress affecting plant growth and productivity worldwide. Therefore, understanding crop response to this stress is very important. There are significant differences in the tolerance of plants to drought stress depending upon intensity and duration of stress, plant species and the development stage (Singh et al., 2013).

Drought impacts include growth, yield, membrane integrity, pigment content, osmotic adjustment, water relations, and photosynthetic activity (Benjamin and Nielsen, 2006; Praba et al., 2009). 


\section{Materials and Methods}

The study was conducted using eight genotypes (Two drought tolerant and six drought susceptible) in randomized block design with three replications. The eight varieties of Coriandrum sativum namely Rcr20, Rcr-446 (Drought tolerant) and Rcr-41, Rcr-435, Rcr-436, Rcr-475, Rcr-684 and Rcr728 (Drought susceptible) were grown in field. In field the varieties were grown in randomized block design with control and drought conditions. Under control condition the plants were irrigated at flowering and seed formation stage while in drought the plants were maintained under rainfed condition. Observation was taken from all the plots between 10 A.M. to 12 noon. Observations on relative water content (RWC), chlorophyll content, Carotenoids, proline content and Membrane stability index (MSI) were taken twice, first at flowering and second at seed forming stage. Observation on 50 Per Cent flowering was taken when half of the plants in a plot flowered. Plant height, number of umbel per plant and seeds per umbel, umbellets per umbel were measured at time of harvesting, whereas, test weight, seed yield, harvest index, biological yield, and drought susceptibility index were measured after harvesting and threshing of the crop.

\section{Results and Discussion}

A reduction due to drought stress was noted in morpho- physiological parameters like relative water content (RWC), chlorophyll content Carotenoids, Membrane stability index (MSI) drought susceptibility index. While biochemical parameter like proline content is increase. Yield and yield contributing parameters like plant height, number of seeds per plant and seeds per umbel, umbellets per umbel, test weight, seed yield, harvest index, biological yield whereas days to 50 Per cent flowering was noted earlier under drought condition than control condition. However, the degree of reduction or increase varied significantly among the varieties. Water stress is the major environmental stress, which limit the growth and productivity of crop in arid and semi-arid regions (Osmond et al., 1980). Tolerant genotypes try to maintain the physiological process by maintaining the water status either by reducing the water losses or by increasing the absorption of water (Larcher, 2004). Coriander crop responds to water stress in the form of changes in various physiological, biochemical and molecular processes. Research on water stress tolerance mechanisms in Coriander has gained momentum in many laboratories around the world.

Result of present study showed that the relative water content decreased significantly in all the varieties at both flowering and seed formation stage during drought condition (Tables 1 and 2). The mean reduction in relative water content was about 8.38 per cent at both stages.

Leaf relative water content (LRWC) is an important physiological attributes which determines the tolerance of plants to drought stress (Sanchez-Blanco et al., 2002).

In present investigation a significant and positive correlation of relative water content with seed yield was observed at flowering and seed formation stages. Thus, varieties like Rcr-446 and Rcr-728 maintained higher relative water content to other varieties is important or registering less reduction under drought compared to control. Other researchers have also reported that the tolerant varieties maintain higher relative water content under stress condition (Desmukh and Kushwaha, 2002). The varieties varied significantly for days to 50 per cent flowering under stress and the mean reduction was 11.83 per cent. 
Table.1 Variations in Drought Susceptibility Index (DSI) among coriander varieties influenced by drought condition

\begin{tabular}{lc}
\hline Varieties & DSI \\
\hline Rcr-20 & 0.94 \\
Rcr-41 & 0.46 \\
Rcr-435 & 1.55 \\
Rcr-436 & 1.61 \\
Rcr-446 & 1.01 \\
Rcr-475 & 0.71 \\
Rcr-684 & 0.88 \\
Rcr-728 & 1.01 \\
\hline SEm \pm & 0.010 \\
CD $(\mathrm{P}=0.05)$ & 0.031 \\
\hline
\end{tabular}

Table. 2 Variations in days to $50 \%$ flowering among coriander varieties under drought conditions

\begin{tabular}{lccc}
\hline Varieties & \multicolumn{3}{c}{ Days to 50\% flowering } \\
\cline { 2 - 4 } & Control & Drought & Mean \\
\hline Rcr-20 & 61.80 & 52.51 & 57.16 \\
Rcr-41 & 65.60 & 53.52 & 59.56 \\
Rcr-435 & 58.50 & 55.95 & 57.23 \\
Rcr-436 & 62.30 & 57.91 & 60.11 \\
Rcr-446 & 68.21 & 54.38 & 61.30 \\
Rcr-475 & 61.32 & 55.87 & 58.60 \\
Rcr-684 & 63.52 & 55.61 & 59.57 \\
Rcr-728 & 69.20 & 64.35 & 66.78 \\
Mean & 63.81 & 56.26 & \\
\hline & SEm \pm & CD $(\mathrm{p}=0.05)$ & \\
Variety (V) & 1.08 & 3.12 & \\
Stress (S) & 0.54 & 1.56 & \\
V x S & 1.53 & 4.41 & \\
\hline
\end{tabular}


Table.3 Variations in number of umbles per plant among coriander varieties under drought conditions

\begin{tabular}{|c|c|c|c|}
\hline \multirow[t]{2}{*}{ Varieties } & \multicolumn{3}{|c|}{ Number of umbels per plant } \\
\hline & Control & Drought & Mean \\
\hline Rcr-20 & 35.20 & 31.50 & 33.35 \\
\hline Rcr-41 & 43.60 & 35.53 & 39.57 \\
\hline Rcr-435 & 35.60 & 30.52 & 33.06 \\
\hline Rcr-436 & 34.10 & 32.80 & 33.45 \\
\hline Rcr-446 & 32.91 & 28.82 & 30.87 \\
\hline Rcr-475 & 32.60 & 27.92 & 30.26 \\
\hline Rcr-684 & 39.80 & 25.88 & 32.84 \\
\hline Rcr-728 & 38.20 & 32.25 & 35.23 \\
\hline \multirow[t]{2}{*}{ Mean } & 36.50 & 30.65 & \\
\hline & SEm \pm & $\mathrm{CD}(\mathrm{p}=0.05)$ & \\
\hline Variety $(\mathrm{V})$ & $0.94^{-}$ & 2.71 & \\
\hline Stress $(\mathrm{S})$ & 0.47 & 1.36 & \\
\hline $\mathrm{V} \times \mathrm{S}$ & 1.33 & 3.83 & \\
\hline
\end{tabular}

Table.4 Variations in number of seeds per umbel among coriander varieties under drought conditions

\begin{tabular}{|c|c|c|c|}
\hline \multirow[t]{2}{*}{ Varieties } & \multicolumn{3}{|c|}{ Number of seeds/umbel } \\
\hline & Control & Drought & Mean \\
\hline Rcr-20 & 34.10 & 30.80 & 32.45 \\
\hline Rcr-41 & 35.40 & 32.20 & 33.80 \\
\hline Rcr-435 & 32.80 & 28.10 & 30.45 \\
\hline Rcr-436 & 31.20 & 25.60 & 28.40 \\
\hline Rcr-446 & 29.20 & 24.20 & 26.70 \\
\hline Rcr-475 & 30.40 & 25.70 & 28.05 \\
\hline Rcr-684 & 26.20 & 22.10 & 24.15 \\
\hline Rcr-728 & 34.10 & 25.80 & 29.95 \\
\hline Mean & 31.68 & 26.81 & \\
\hline & SEm \pm & $\mathrm{CD}(\mathrm{p}=0.05)$ & \\
\hline Variety (V) & $0.80^{-}$ & 2.30 & \\
\hline Stress (S) & 0.40 & 1.15 & \\
\hline $\mathrm{V} \times \mathrm{S}$ & 1.13 & 3.26 & \\
\hline
\end{tabular}


Table.5 Variations in umbellates per umbel among coriander varieties under drought conditions

\begin{tabular}{|c|c|c|c|}
\hline \multirow[t]{2}{*}{ Varieties } & \multicolumn{3}{|c|}{ Umbellates/umbel } \\
\hline & Control & Drought & Mean \\
\hline Rcr-20 & 4.25 & 3.90 & 4.08 \\
\hline Rcr-41 & 5.30 & 4.10 & 4.70 \\
\hline Rcr-435 & 4.80 & 4.15 & 4.48 \\
\hline Rcr-436 & 4.60 & 3.90 & 4.25 \\
\hline Rcr-446 & 4.70 & 3.85 & 4.28 \\
\hline Rcr-475 & 4.50 & 3.60 & 4.05 \\
\hline Rcr-684 & 3.90 & 3.15 & 3.53 \\
\hline Rcr-728 & 5.15 & 4.10 & 4.63 \\
\hline Mean & 4.65 & 3.84 & \\
\hline & SEm \pm & $\mathrm{CD}(\mathrm{p}=0.05)$ & \\
\hline Variety (V) & $0.10 \overline{7}$ & 0.309 & \\
\hline Stress (S) & 0.054 & 0.155 & \\
\hline $\mathrm{V} \times \mathrm{S}$ & 0.151 & 0.437 & \\
\hline
\end{tabular}

Table.6 Variations in test weight (g) among coriander varieties under drought conditions

\begin{tabular}{|c|c|c|c|}
\hline \multirow[t]{2}{*}{ Varieties } & \multicolumn{3}{|l|}{ Test weight } \\
\hline & Control & Drought & Mean \\
\hline Rcr-20 & 12.10 & 11.60 & 11.85 \\
\hline Rcr-41 & 11.30 & 11.10 & 11.20 \\
\hline Rcr-436 & 12.30 & 12.06 & 12.18 \\
\hline Rcr-446 & 12.58 & 11.20 & 11.89 \\
\hline Rcr-475 & 13.50 & 12.78 & 13.14 \\
\hline \multirow{2}{*}{ Mean } & 12.57 & 11.81 & \\
\hline & SEm \pm & $\mathrm{CD}(\mathrm{p}=0.05)$ & \\
\hline Variety (V) & 0.37 & 1.06 & \\
\hline Stress (S) & 0.18 & 0.53 & \\
\hline $\mathrm{V} \times \mathrm{S}$ & 0.52 & NS & \\
\hline
\end{tabular}


Int.J.Curr.Microbiol.App.Sci (2017) 6(8): 729-736

Table.7 Variations in seed yield (g/plant) among coriander varieties under drought conditions

\begin{tabular}{lccc}
\hline Varieties & Control & Seed yield & Mean \\
\cline { 2 - 4 } & 5.30 & 5.00 & 5.15 \\
Rcr-20 & 6.01 & 5.10 & 5.56 \\
Rcr-41 & 5.60 & 4.30 & 4.95 \\
Rcr-435 & 5.40 & 4.10 & 4.75 \\
Rcr-436 & 4.92 & 4.80 & 4.86 \\
Rcr-446 & 5.15 & 4.60 & 4.88 \\
Rcr-475 & 4.40 & 3.82 & 4.11 \\
Rcr-684 & 5.82 & 4.50 & 5.16 \\
Rcr-728 & 5.33 & 4.53 & \\
Mean & SEm+ \pm & \\
\hline & 0.16 & CD $(\mathrm{p}=0.05)$ & 0.47 \\
Variety (V) & 0.08 & 0.23 & 0.66 \\
Stress (S) & 0.23 & & \\
V S S & &
\end{tabular}

Table.8 Variations in plant height $(\mathrm{cm})$ among coriander varieties under drought conditions

\begin{tabular}{|c|c|c|c|}
\hline \multirow[t]{2}{*}{ Varieties } & \multicolumn{3}{|c|}{ Plant height } \\
\hline & Control & Drought & Mean \\
\hline Rcr-20 & 64.10 & 60.20 & 62.15 \\
\hline Rcr-41 & 63.00 & 61.30 & 62.15 \\
\hline Rcr-435 & 69.50 & 58.60 & 64.05 \\
\hline Rcr-436 & 65.60 & 59.20 & 62.40 \\
\hline Rcr-446 & 69.20 & 60.00 & 64.60 \\
\hline Rcr-475 & 64.10 & 57.00 & 60.55 \\
\hline Rcr-684 & 70.30 & 58.90 & 64.60 \\
\hline Rcr-728 & 72.00 & 54.50 & 63.25 \\
\hline Mean & 67.23 & 58.71 & \\
\hline & SEm \pm & $\mathrm{CD}(\mathrm{p}=0.05)$ & \\
\hline Variety (V) & 1.65 & 4.76 & \\
\hline Stress (S) & 0.82 & 2.38 & \\
\hline $\mathrm{V} \times \mathrm{S}$ & 2.33 & 6.74 & \\
\hline
\end{tabular}


This reduction indicates that drought condition caused some metabolic changes in the Coriander plants conversion from vegetative phase to reproductive phase. Water stress decreased number of pods per plant at 50 per cent flowering stage in chickpea (Hamid et al., 1990). Water stress induced reduction in growth parameters was also reflected in number of seeds per pod, number of pods per plant and seed index. Plant height varied significantly among the varieties under control as well as drought conditions. The mean reduction under drought condition was 12.67 per cent. Singh and Choudhary (2003) reported that mean performance of genotypes for plant height was comparatively low under stress condition and reported 15.7 reduction due to stress for plant height.

Result on seed yield indicated that Rcr-446 exhibited maximum yield under control condition which was closely followed by Rcr20 and Rcr-435. In contrast Rcr-446 exhibited maximum yield under drought condition which was closely followed by Rcr-728 and Rcr-41. These variations in yield were found attribute to the variations in yield contributing parameters vis-a-vis existence of drought tolerance mechanism at cellular and molecular level. In present investigation the highest yield of Rcr-446 under drought condition might be on account of better performance of this variety to yield contributing parameters like umbels per plant, seeds per umbel, umbellets per umbel, test weight, biological yield and harvest index. These parameters have been found positively correlated with seed yield indicating their influence on determination of yield (Tables 3-8).

Water stress caused decrease in biological yield as compared to non-stress condition. Biological yield is an important criterion for improvement in yield, which is strongly influenced by the environment (Kumar et al.,
2001). Harvest index, as an important criterion for improvement in the yield, strongly influenced by environment. Drought susceptibility of a genotype is often measured as a function of the reduction in yield under drought stress (Blum, 1988). Yield is the most important parameter for a crop. However, the yield contributing parameters are different in cereals, pulses, oilseed and seed spices crops. In case of Coriander, we have measured yield in control as well as water stress condition. In the present study, there is reduction in yield due to water stress at both the stages. The decrease was more in seed formation as compared to flowering in water stress. In the present study, genotypes Rcr-20 and Rcr-446 were less affected by water stress at both the stages. These results are supported by other parameters studied in this study. Thus it can be concluded that, an extensive water stress tolerance mechanism is active in coriander crop for both the stages.

In conclusion, the coriander varieties $\mathrm{RCr}-20$ and $\mathrm{RCr}-446$ behaved as drought tolerant varieties and maintained higher seed yield along with number of umbels per plant, seeds per umbel, umbellets per umbel, test weight, seed yield, biological yield and harvest index. All these traits of the varieties helped them to maintain lower drought susceptibility index. The correlation analysis indicated that most of the physiological and parameters had positive and significant correlation with seed yield of coriander both at flowering and seed formation stages. Further the correlation coefficient of yield attributes with seed yield of coriander showed a positive and significant correlation with most of the characters except total chlorophyll content and days to 50 per cent flowering.

\section{Acknowledgements}

The authors are thankful to the Head, Department of Plant Physiology, SKN 
College of Agriculture (SKN Agriculture University) Jobner, Jaipur, Rajasthan (India) for providing facilities to carry out the present study.

\section{References}

Anonymous, 2015-16. Vital Agriculture Statistics. Commission rate of Agriculture, Rajasthan, Jaipur, pp. 1819.

Benjamin, J.G. and Nielsen, D.C. 2006. Water deficit effects on root distribution of soyabean, field pea and chickpea. Field Crop Research, 97: 248-253.

Blum, A. 1988. Plant breeding for stress. Environments CRC Press, Boco Raton, Florida, pp. 233.

Deshmukh, P.S. and Kushwaha, S.R. 2002. Variability in membrane injury index in chickpea genotypes. Indian Journal of Plant Physiology, 7: 285-287.

Hamid, A., Kubota, F., Agata, W. and Morokowa, M.1990. Photosynthesis transpiration, dry matter accumulation and yield performance in mungbean plant in response to water stress. Journal of Faculty Agriculture, 35: 8182.

Kumar, P., Deshmukh, P.S., Kushwaha, S.R. and Sunita Kumari. 2001. Effect of terminal drought on biomass production on its partitioning and yield of chickpea genotypes. Annals of Agriculture Research, 22: 408-411.

Larcher, A. 2004. Physiological plant ecology. Springer Verlag, Berlin.

Osmond, C.B., Bijorkmon, O. and Anderson, D.J. 1980. Physiological processes in plant ecology. Springer Verlag, Berlin.

Praba, M.L, Cairns, J.E., Babu. R.C. and Lafitte, H.R. 2009. Identification of physiological traits underlying cultivar differences in drought tolerance in rice and wheat. Journal of Agron Crop Science, 195: 30-46.

Sanchez-Blanco M.J., Rodriguez P., Morales M.A., Ortuno M.F. and Torrecillas A. 2002 Comparative growth and water relation of Cistus albidus and Cistus monspeliensis plants during water deficit condition and recovery. Plant Science, 162: 107-113.

Singh, S. P. and Choudhary, A. K. 2003. Selection criteria for drought tolerance in Indian mustard. Indian Journal of Genetics, 63: 263-264.

Singh, S.J. and Singh, S. K. 2013. Genetic variability analysis in coriander (Coriandrum sativum L.). Journal of Spices and Aromatic Crops, 22: 81-84.

\section{How to cite this article:}

Mamta Bajya, B.L. Kakralya, Kamlesh Jangid and Anita Burdak. 2017. Estimation of the Effect of Drought on Yield and Yield Contributing Traits in Coriander Genotypes (Coriandrum Sativum L.). Int.J.Curr.Microbiol.App.Sci. 6(8): 729-736.

doi: https://doi.org/10.20546/ijcmas.2017.608.093 